\title{
An Assessment of Stakeholder Participation in Monitoring and Evaluation of District Assembly Projects and Programmes in the Savelugu- Nanton Municipality Assembly, Ghana
}

\author{
Mohammed Sulemana \\ University for Development Studies, Wa Campus, Ghana \\ mohammedsule88@yahoo.co.uk \\ Alhassan Baba Musah \\ University for Development Studies, Wa Campus, Ghana \\ and \\ Kanlisi Kaba Simon \\ University for Development Studies, Wa Campus, Ghana \\ DOI//http://dx.doi.org/10.4314/gjds.v15i1.9
}

\begin{abstract}
Participatory Monitoring and Evaluation (PM\&E) of projects and programmes promotes greater transparency and accountability in development governance. Some studies revealed that participation in Metropolitan, Municipal and District Assemblies in monitoring and evaluation (M\&E) is low. This study adopted a case study approach. A sample of 196 people participated in the study. The study revealed that stakeholder participation in M\&E of projects and programmes was high among the Municipal Planning and Co-ordinating Unit (MPCU) members and the District Assembly members but low at the Zonal Council and community levels. This has impacted negatively on the transparency, accountability and the sustenance of projects and programmes. The study concludes that stakeholders were rarely involved in M\&E of projects and programmes due to lack of concerted effort by the MPCU for grass root stakeholder participation and poor attitude on the part of community level stakeholders in M\&E of projects and programmes. The MPCU and the Assembly members' involvement were appreciably high whereas the Unit committee, the community and the Zonal councils' involvement were low. The study recommends that the District Assembly through the MPCU should establish strategies
\end{abstract}


such as increased engagement of the substructures in the planning, implementation, monitoring and evaluation process, creating an enabling environment for the substructures to set their own targets, support them to meet the targets and build their capacities to report regularly to communities under them and to the Municipal Assembly. The Municipal Assembly should partner with the Sub-structures to embark on community sensitization on participatory monitoring and evaluation of projects and programmes.

Keywords: Participatory Monitoring and Evaluation, Stakeholders, Community Participation, Projects, Programmes, Savelugu-Nanton

\section{Introduction}

Participatory monitoring and evaluation has been triggered by the value and need for basing development on the views and priorities of 'the local population' which has become widely acknowledged over the last decades, leading to a practice of working with and by communities (Hilhorst \& Guijt, 2006:6). Initially pioneered by action research-oriented initiatives and organisations, the use of participatory approaches and methods has become increasingly mainstreamed. The use of tools such as social mapping, Venn diagrams, wealth ranking, and transects have become normal practice in much development work (Hilhorst \& Guijt, 2006:6). This led to ministries beginning to include participatory methodologies in guidelines provided to local governments for developing municipal development plans, such as in Benin and Mali. Participatory diagnosis, priority setting, and planning have become an accepted ethic and are practiced in hundreds of Northern and Southern development initiatives. However, it became important that 'participation' should also address implementation, monitoring and evaluation. There is a rapidly growing interest in ensuring wider participation, and since the mid-1990s, participatory Monitoring \& Evaluation (PM\&E) has received increasing attention (Hilhorst \& Guijt, 2006:6).

Over the past ten years, PM\&E has gained importance over more conventional approaches to M\&E. Whereas M\&E in the past has been judgmental, PM\&E seeks to involve all key stakeholders in the process of developing framework for measuring results and reflecting on the projects' achievement and proposing solutions based on local realities (Coupal, 2001:2). In Ghana, the Local government plays very important roles in administration and development at the local areas. The 1992 Constitution of the Republic of Ghana provides for "Decentralisation and Local Government" that creates a framework for citizens' participation in decisionmaking and local governance. The decentralisation Policy of Ghana devolves power, functions and responsibility as well as human and financial resources 
from the Central Government to the district level. It also establishes major areas of relationship between the Local and Central Government (ILGS, 2010:9). Ghana's decentralisation process as enshrined in the Constitution designates District Assemblies as the highest political, legislating, budgeting and planning authority at the local level. The Local Government Act (Act 462) of 1993 reinforces the constitutional provisions. To facilitate a holistic approach to the decentralisation process, various structures have been created at the sub-national level with the Regional Coordinating Council (RCC) as a coordinating body. Below the RCC are the Metropolitan Municipal and District Assemblies (MMDAs) and the Sub-district structures (ILGS, 2010:9). Section 46, Sub-section 4 of the Local Government Act, 1993, Act 462 requires that the Metropolitan Municipal and District Assemblies (MMDAs) and Sector Departments employ a participatory approach in the planning, design, M\&E of projects and programmes.

It is important to note that active participation matters not only as a means of improving development effectiveness but also as the key to long-term sustainability and leverage (World Bank, 1998:1). Participation refers to the engagement of stakeholders in the development process in order to ensure that the intended benefits of projects and programmes reach the communities in focus. Although there is no commonly agreed definition of Participatory Monitoring and Evaluation, the World Bank (2010a) indicates that it is "a process through which stakeholders at various levels engage in monitoring or evaluating a particular project or programme or policy, share control over the content, the process and the results of the monitoring and evaluation activity and engage in taking or identifying corrective actions".

There are variants of participation in the development process including active participation and passive participation. In between these two are other variants including coercion, manipulation, consultation, food for work and information giving. Collins (1996:3) indicated that the empowerment of beneficiaries and stakeholders can help sustain a project beyond the disbursement period due to enhanced capacities and ensure an increased level of beneficiary and stakeholder interest in project management. In addition, enhancing stakeholders perceived ownership especially; the beneficiaries can often be directly linked to improved maintenance of the project and therefore further contributes to its sustainability in the long term.

The Institute of Development Studies (1998) noted that providing stakeholders the chance to participate in M\&E becomes an opportunity for development organisations to focus better on their ultimate goal of improving poor people's lives and broadening involvement in identifying change of which a clearer picture can be 
gained of what is really happening on the ground. This can also be an empowering process since the skills of the people in charge are developed and show also that their views count (IDS, 1998:1). Nyaguthii and Oyugi (2013:9) stated that involving the local residents in monitoring of projects would increase the level of satisfaction for the beneficiaries.

Hilhorst and Guijt (2006:3) noted that while primary stakeholders are increasingly involved in some aspect of planning, their presence within the M\&E of actions is very often lacking or inadequate. Ahenkan, Bawole and Domfer (2013:206) also observe that there are no clear structures and procedures for community involvement in the monitoring of development interventions in the districts though some structures for promoting community engagement during planning processes exist.

Hilhorst and Guijt (2006:43), pointed out that access to complete project information provides people with a sound basis to voice their concerns and needs, which can be incorporated into project activities. Moreover, wide public dissemination helps to place control in the hands of communities and mitigates risks of manipulation by other actors and that once the project begun it is important to ensure that the communities stay informed, receive feedback on progress at different stages. Oreyo, Munyua and Olubandwa (2016:82) stated that PM\&E enhanced good governance with increased accountability, responsiveness to the needs of the citizens and level of transparency. Devas and Grant (2003:313) argued that there are still problems of lack of transparency, with publicly displayed information often being out of date and inaccessible to the majority because of the location of display or the language used and there continue to be major problems over corruption, rent seeking, abuse of tender procedures and poor relationships between paid officials and elected representatives.

Ahenkan et al. (2013:208) argued that the lack of space for stakeholder participation has constrained the promotion of effective, responsive and responsible government at the local level for poverty reduction and that procedures and structures for community engagement in monitoring and evaluation of development interventions seldom exist. Alfred (2015) also argued that there is a low level of stakeholder involvement in infrastructure project monitoring among MMDAs due to lack of public education, lack of collaboration between management and beneficiaries and poor monitoring information dissemination.

As a result, many programmes and projects today have been introduced and developed with participatory approaches so as to bring the different voices of the people into the development process as active participants rather passive 
observers. When stakeholders become active participants in the project and programme monitoring process, they add an intrinsic value by holding duty bearers accountable for their omissions and commissions. However, when they become passive participants, value for money cannot be guaranteed, which negatively affects the sustainability of projects/programmes. Even the Medium Term Development Plan of District Assemblies has a PM\&E component that allows for the involvement of beneficiary community, civil society and the District Planning and Co-ordinating Unit (DPCU). This is evident in Section 46, Sub-section 3 of the Local Government Act, 1993, Act 462 which established the District Planning and Co-ordinating Unit (DPCU) to assist the District Assembly to execute designated planning functions. The National Development Planning (System) Act, 1994, Act 480 defines the DPCU's planning, programming, monitoring, evaluation and coordinating functions.

Taking into consideration Ahenkan, et al. (2013:208) and Alfred (2015) the legal framework that supports the involvement of stakeholders in M\&E, it seems to suggest that the process of involving stakeholders in M\&E of projects and programmes have not been very effective.

More emphasis has always been on participatory planning and it is worth noting that participatory planning is not an end in itself but a means to an end, which is the involvement of the stakeholders also in M\&E of projects and programmes to achieve the desired outputs and outcomes. This may be the cause of many poorly executed projects since contractors, consultants and officers in charge take advantage of the insufficient participation of the beneficiary communities and other stakeholders to circumvent the process without following the contract specifications of projects and programmes. In the case of the Savelugu-Nanton Municipal Assembly, the M\&E plan of 2010 included Assembly members and local communities as part of stakeholders in the planning, implementation, monitoring and evaluation of projects and programmes in the district but however indicated also that the MPCU needs capacity building in participatory monitoring and evaluation (DPCU, SNDA, 2010). There has also been poor state of office infrastructure of the Zonal councils, declining communal spirit in development interventions and low level of women participation in local level governance in the District (MPCU,SNMA, 2015).

Several years since the introduction of decentralization in Ghana, MMDAs have not fully integrated participatory monitoring and evaluation in the management of the districts. This situation has been given credence by various studies conducted on monitoring and evaluation and its effectiveness at the Local Government level elsewhere in the southern Ghana, where the culture is generally different and 
poverty is not as prevalent as compared to northern Ghana. In instances where poverty is more widespread, the expectation is that communities will embrace external support through their active participation in order to make projects and programmes initiated very successful. This has, however, not yet been empirically tested in the Savelugu-Nanton Municipal Area. This paper therefore seeks to investigate the level of stakeholder participation in M\&E of development projects and programmes and its effect on projects and programmes in the SaveluguNanton Municipal Assembly.

\section{Theoretical and Conceptual Perspectives}

\section{PM\&E and Conventional M\&E}

Shah, Mahlalela, Kambou and Adams (2006:8) stated that PM\&E differs significantly from conventional M\&E in that the community, beneficiaries, and people involved in designing and implementing the project are also involved in M\&E throughout the project's duration. Conventional M\&E focuses on the measurement of results - service delivery, information dissemination, behaviour change while participatory monitoring and evaluation focuses on the results and process.

For any Participatory Monitoring and Evaluation process to yield the intended outcomes, it must involve stakeholder inclusion, collaboration, collective action, and mutual respect. It must encourage dialogue at the grassroots level and move the community from the position of passive beneficiaries to active participants with the opportunity to influence the project activities based on their needs and their analysis.

Rajalahti, Woelcke and Pehu (2005:35) indicates that increased attention on poverty reduction and socially sustainable development embracing the social and cultural diversity among targeted populations has increased the need to engage in direct dialogue with different stakeholder groups involved in development projects. One critical dimension of this engagement is monitoring and evaluating projects and programmes with the full and active participation of stakeholders. The reflections of Coupal (2001:3) on the purpose of PM\&E have implications for capacity building of local project stakeholders to enable them reflect, analyse, propose solutions; take action and to learn, adjust through corrective action to ensure the achievement of results such as adding or deleting activities or changing one's strategies and also to celebrate and build on what is working. 
According to Sulemana and Ngah (2012) to establish whether a process of community development is participatory or not, the following questions have to be asked "was the community involved in problem identification, goal formulation, objective setting, identification of project options, choice making, implementation, monitoring and evaluation? Did community members contribute (in terms of labour, finance and other materials, share in the benefits that accrue from the process"? If the answer to any of the above questions is 'no' then the outcome of the process is not participation.

The emphasis on the involvement of beneficiaries is paramount as opposed to conventional M\&E and therefore the design of development projects and programmes needs to factor in a participatory approach that is effective. The study is not only interested in the "technical" point of view of the implementing agency (District Assemblies, project managers) only but also the non-technical views of the people at the grassroots or the beneficiary community. The resulting analysis will generate lessons or best practices that are fed back to improve the performance and sustainability of projects. The process is meant to strengthen the capacity and awareness of the participating stakeholders of the various projects and programmes. This is why Kusek and Rist (2004:20) argued that monitoring and evaluation promotes greater transparency and accountability within organisations and governments and beneficial spill over effects may also occur from shining a light on results where external and internal stakeholders will have a clearer sense of the status of projects, programs, and policies.

It is our considered opinion that the ability to demonstrate positive results can also help garner greater political and popular support. Hence, the available literature indicates that PM\&E ensures that stakeholders at all levels should be engaged at all stages of the project/programme. At each level, however, there are specific objectives for M\&E as well as stakeholder roles. For PM\&E to be effective there is the need for the creation of a mechanism and channels that gives feedback to all stakeholders involved at all levels (national, district, community). In effect, PM\&E system is a project and programme management tool that provides information for management decision making which is why the focus of the study then is to assess the level of stakeholder participation in M\&E of projects and programmes.

\section{Typologies of participation}

One of the early proponents of participatory theory on the subject of community participation was Arnstein (1969). In her ladder of participation, she clarified and interpreted different forms of empowerment. Arnstein's model postulates that citizen participation is the redistribution of power that enables the have- 
not citizens, presently excluded from the political and economic processes, to be deliberately included. Arnstein's ladder progresses from less to more levels of meaningful participation and with each level containing some form of empowerment. She used the image of a ladder to portray how social programs can be categorised based on the depth of citizen involvement in the design. The model shows different levels of power sharing between citizens and decision makers over eight rungs. At the bottom two rungs of her ladder are manipulation and therapy which represent participation that is not genuine because authority holders are not making any effort to re-distribute power. The next three levels at the middle of the ladder: informing, consultation, and placation represent forms of tokenism. At these levels of participation those without power are given some chance to communicate their views, but their voices are not translated in to action. At the top of her ladder more views are considered during decision-making processes. Partnerships give citizens, who were previously excluded from decision-making, the opportunity to bargain with those in power. Delegated power and citizen control are at the apex of Arnstein's ladder where previously excluded citizens are able to make decisions (Arnstein, 1969).

Burns, Hambleton and Hoggett (1994) presented a modification of Arnstein's ladder of participation. They proposed a ladder of citizen power making it more elaborate than Arnstein's ladder, with a further, more qualitative breakdown of some of the different levels which they aim to make relevant to local governments in general. For example, a distinction between 'cynical' and 'genuine' consultation, and between 'entrusted' and 'independent' citizen control whilst 'civic hype' is incorporated at the bottom rung of the ladder. Hence, different degrees of delegated power are contained in each area of decision making. Their ladder shows also that there are meaningful types of participation involving some transfer of power from authorities to citizens, allowing them to then gain influence in the decision-making process.

Wilcox (2003) identified five interconnected levels of community participation as a further development of the ladder concept of participation by Arnstein. The theoretical framework of Wilcox shows that the individual who controls a decision-making process is a pivotal element for consideration during the initiation of participation. He indicated that different levels of participation are deemed appropriate in different circumstances. As such, Wilcox altered the rungs of Arnstein to provide organisations and other practitioners with an alternative way to look at the degree to which they are prepared to as a matter of fact involve community members in their processes. He proposed a five-rung ladder of participation including: Information - this has to do with the organisation merely 
telling the people about what is planned (Wilcox, 2003:10). According to Wilcox (2003:11) consultation involves offering some options, listening to feedback. Deciding together - this is when the organisation encourages others to provide some additional ideas and options, and join in deciding the best way forward. Deciding together can also mean accepting other people's views and then choosing from options you have developed together (Wilcox, 2003:12). Acting together This is the stage at which different interests decide together on what is best and also form a partnership to execute the decisions (Wilcox, 2003:12). Supporting independent community interests - this means helping the people to develop and carry out their own plans. Resource holders or organizations who promote this stance may, of course, offer local groups or organisations with funds, advice or other support to develop their own agendas within guidelines. The basics of this stance is that it is the most 'empowering' level of participation provided to people who want to do things for themselves (Wilcox, 2003:13).

According to Wilcox (2003:9), participation can be effective when each of the key interests (stakeholders) are satisfied with the level of participation. That is, those who do not have much at stake may be happy to be informed or consulted whilst others will want to be involved in decisions and possibly take action. The difficult task for the practitioner or the organisation managing the process will be to identify these interests, try to help them work out what they want, and negotiate a route for them to achieve their interests.

The theories of participation by Arnstein (1969), Burns et al. (1994) and Wilcox (2003) were thus the theoretical underpinnings of this study. The study sought to assess the level of participation of stakeholders in M\&E of development projects and programmes in the Savelugu-Nanton Municipal Assembly in the Northern Region of Ghana using the ladder theory of participation. The ladder model is considered to be very useful in determining the level of participation by stakeholders of M\&E.

\section{Conceptual Framework}

The framework in Figure 1 which has been conceptualised for the analysis of variables show that the local government system plays a key role in the Ghanaian economy in adopting participatory approaches to development. The decentralisation policy adopted by Ghana in 1988 is part of ways of using the PM\&E methodology as one of the key project management strategies of the local government system. This was regarded as a means of devolving power to the people in order to enhance democracy and accountability and improve service delivery at the local community level. Therefore, the framework shows that local government 
is an initiative that directly emanated and brought about the district assembly and zonal council structures as a tool to reaching out easily to the beneficiaries of development. The assumption here is that the district assemblies and the Zonal councils through the Institutional frame work for planning, programming, M\&E are performing their obligatory duties especially organising M\&E in consultation and effective involvement of all stakeholders.

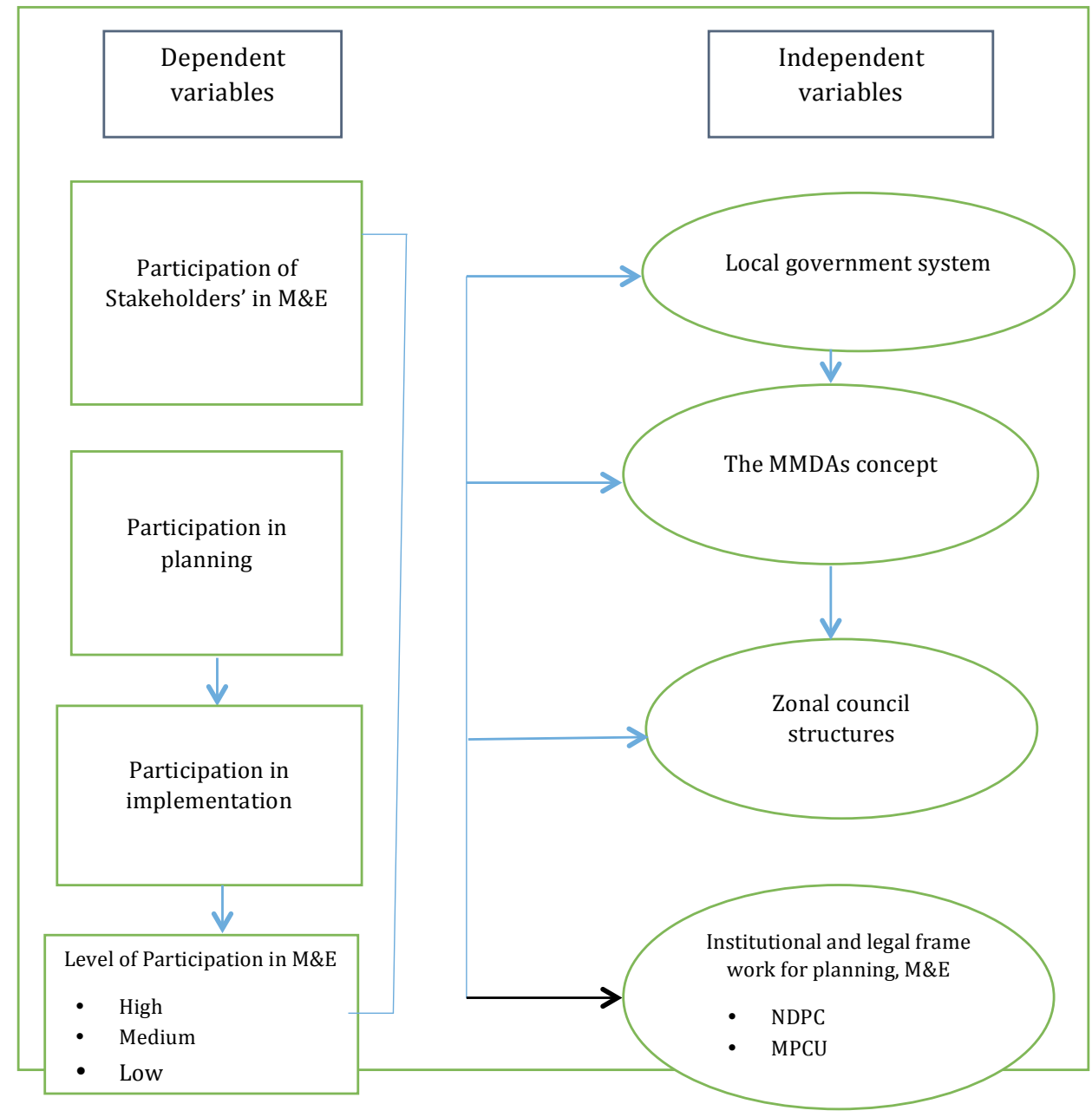

\section{Figure 1: Conceptual framework}

Source: Author's construct, 2018

The Africa Development Bank (2001:2) noted the existence of six progressive levels of stakeholder involvement. The first three levels (information-sharing, listening and learning and joint assessment) constitute consultation, rather than participation as such. These levels might be considered as prerequisites for 
participation. The next three levels (shared decision-making, collaboration and, finally, empowerment) constitute progressively deeper and more meaningful levels of participation. As one moves from "shallower" to "deeper" levels of participation, stakeholders have greater influence and control over development decisions, actions and resources.

Ahenkan et al. (2013:200) established that assembly members are stakeholders with very high interest in the development of their district. However, the assembly members find it difficult to access information about the district's projects and programmes (Ahenkan, Bawole and Domfer, 2013:202). Hilhorst and Guijt (2006:21) observe that multi-stakeholder process may be subject to elite capture or illegitimate participation limiting marginalised groups to organise themselves in ways that enable active engagement and may be less well informed with information reaching them only through community leaders. This is why in most cultures men tend to dominate every aspect of public participation and leadership. There is also a considerable belief that men are better placed to deal with strangers and ensure community interests in promoting development (Oreyo, Munyua and Olubandwa, 2016:84). In its report, the UNDP (2009:15) noted that to ensure community ownership of development projects men, women and traditionally marginalised groups should be involved in the planning,monitoring and evaluation processes.

\section{Research Methodology}

\section{Study Area}

The Savelugu-Nanton Municipal Assembly (SNMA) is located at the northern part of the Northern Region of Ghana. It shares boundaries with West Mamprusi to the North, Karaga to the East, Kumbungu to the West and Tamale Metropolitan Assembly to the South. The altitude of the Municipal Assembly ranges between 122 and 244 metres above sea level. The assembly also has a total land area of about $2022.6 \mathrm{sq}$. km. with a population density of 68.9 persons per sq. km (GSS, 2014). The study was conducted in SNMA which was carved out of the Western Dagomba District Council under the PNDC Law 207 in 1988. This Law was replaced by the Legislative Instrument (LI) 1450 under the Local Government Act 1993 (Act 462). In March 2012, the Assembly was up-graded to a Municipal status under the Legislative Instrument (LI) 2071. The Municipal Assembly has a total population of 139,283 (GSS, 2014) comprising 67,531 males (48.5\%) and 71,752 females (51.5\%). The Municipality has a sex ratio of 94.1 males per 100 females. Meanwhile six out of 
every ten persons in the District reside in the rural areas (60.3\%) which mean that the municipality is predominantly rural.

\section{Study Approach, Design and Data Collection}

A single case study approach was used to obtain necessary data in order to assess the level of stakeholder participation in M\&E in the Savelugu-Nanton Municipal Assembly (SNMA). The focus was to devote careful attention (Yin, 2004; 2009) to the participatory monitoring and evaluation (PM\&E) phenomena in the Municipality which could provide useful lessons for other MMDAs in Ghana. The maximum variation case study approach was considered appropriate because in spite of the fact that the researchers explored in depth the M\&E activities and processes or one or more individuals (Creswell, 2009: 113), the extent of knowledge of study participants and opinion on the subject matter under investigation vary. This gave the researchers the opportunity to collect detailed information using a variety of data collection procedures over a sustained period of time (Creswell, 2009:13). The predominant data type was qualitative, notwithstanding the indispensability of some amount of quantitative data. The study used semi-structured interview guide and questionnaire as tools for data collection. Semi-structured interviews were conducted and questionnaires administered as methods of data collection to ensure an extensive examination and understanding of the phenomenon as well as the dynamics of participation of stakeholders in M\&E and the outcome of programmes and projects delivery in the study area. The data collection process involved three response categories including the Municipal Planning Co-ordinating Unit (MPCU) at the municipal level and the assembly members, zonal council members', unit committee members as sub-structure response category and the beneficiary community response category. As Kothari (2004:175) stated, whenever a sample study is made there arises some sampling error which can be controlled by selecting a sample of adequate size and that the researcher will have to specify the precision that he wants in respect of his estimates concerning the population parameters. In view of this, a 2.5\% margin of error was allowed at $97.5 \%$ level of precision in determining the true population value within the range of precision indicated. The confidence level of $97.5 \%$ gives a $z$-score of 2.243 from the standard normal distribution table. Given a population defectiveness rate of $2.5 \%$ (p) of the stakeholders of M\&E at the Savelugu Municipal Assembly in the Northern region of Ghana and to obtain a conservative estimate of the sample size required, $q$ will be set at (1-p) often used to determine the sample size that will achieve the precision indicated. Considering the variables explained above, the sample size determination formula below was adopted to determine the sample size for the study: 
A total of 196 respondents were sampled from the Savelugu-Nanton Municipality Assembly for the study. The study therefore employed purposive non-probability sampling, and the simple random probability sampling method. The purposive sampling was used such that the potential respondents were known in advance, and the selection was based on the fact that they have the relevant knowledge and experience with which to contribute to the study (Flick, 2009:123). The data was analysed qualitatively by sorting and categorising the data that was obtained from the semi-structured interviews and questionnaires according to thematic areas. The qualitative responses were summarised to fit well in the study since they were detailed in nature. The data was also analysed using themes. Precisely the responses from different respondents were compared to determine the most occurring responses and these were used in the analysis and interpretation of the data. The authors developed five-point Likert scales which were applied in determining the level of stakeholder participation in monitoring and evaluation. The data was summarised in the form of narratives and the most important quotations in the field were used to illustrate the main findings of the study. Relevant and secondary data analysis was also used to interpret and discuss the findings of the study. Quantitatively, the statistical package for social scientists (SPSS) was employed to draw correlations and other statistical relationships between variables in the semi-structured questionnaire used.

\section{Results and Discussion}

A total of 196 stakeholders participated in the study. This included 126 community chiefs, elders, women leaders, youth leaders and resident school teachers. At the Local Authority level, 70 respondents participated in the study including 10 members of the Municipal Planning and Co-ordinating Unit, Assembly members, Zonal/Area/Town Council Chairpersons and Unit Committee members (see Table1). 
Table 1: Profile of respondents

\begin{tabular}{|c|c|c|c|}
\hline Category & Sex & Frequency & Percentage \\
\hline \multirow{3}{*}{$\begin{array}{l}\text { Key Informants of Beneficiary } \\
\text { community members }\end{array}$} & Male & 94 & 48 \\
\hline & Female & 32 & 16 \\
\hline & Sub-total & 126 & 64 \\
\hline \multirow{3}{*}{$\begin{array}{l}\text { Sub-structure } \\
\text { Assembly members, zonal council } \\
\text { members and unit committees }\end{array}$} & Male & 55 & 28 \\
\hline & Female & 5 & 3 \\
\hline & Sub-total & 60 & 31 \\
\hline \multirow{3}{*}{$\begin{array}{l}\text { Municipal planning co-ordinating } \\
\text { unit (MPCU) }\end{array}$} & Male & 8 & 4 \\
\hline & Female & 2 & 1 \\
\hline & Sub-total & 10 & 5 \\
\hline \multirow[t]{3}{*}{ All respondents } & Male & 157 & 80 \\
\hline & Female & 39 & 20 \\
\hline & Total & 196 & 100 \\
\hline
\end{tabular}

\section{Stakeholder involvement in project/programme planning, implementation, M\&E}

The study indicated that there is a low level of stakeholder involvement in M\&E of projects and programmes. This is because responses from stakeholders other than MPCU members point to the fact that they are seldom fully involved. The responses, which mimicked the situation on the ground, to a large extent contrasted the view of Institute of Development Studies (1998) that providing stakeholders the chance to participate in M\&E becomes an opportunity for development organisations to focus better on their ultimate goal of improving poor people's lives and broadening involvement in identifying change of which a clearer picture can be gained of what is really happening on the ground. This can also be an empowering process since the skills of the people in charge are developed and show also that their views count (IDS, 1998:1). The study shows that the Municipality does not consciously involve all stakeholders and might not be able to reap the benefits of involving stakeholders especially stakeholders at the beneficiary community level. This is obvious since only few stakeholders of both the MPCU (10\%) and the Assembly's Sub-structures (5.6\%) clearly agreed strongly to the statement that the municipality takes the involvement of stakeholders in monitoring and evaluation seriously and sees it as a critical project management tool (see Figure 1). It must be emphasised that MPCU members consider monitoring and evaluation as a technical activity requiring technical indicators, means of verification and complex assumptions that community members are perceived not to understand. For some MPCU members, 
empowering community members to be part of the major drivers of the monitoring and evaluation process is expensive and time consuming.

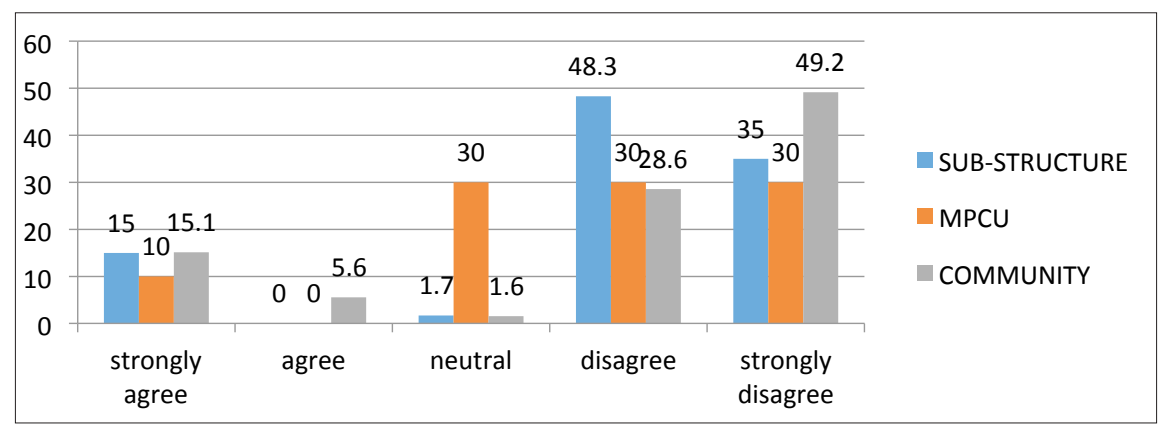

\section{Figure 2: MPCU should be solely responsible for M\&E}

The Municipality might not know that stakeholder participation is capable of increasing beneficiary interest and satisfaction and to some extent their own satisfaction of projects and programmes being implemented as indicated by Nyaguthii and Oyugi (2013:9) when they stated that involving the local residents in monitoring of projects and programmes increases the level of satisfaction for the beneficiaries. As part of measuring the involvement of stakeholders in planning, implementation, M\&E of projects and programmes, it was established that the involvement of the Zonal Council in planning and implementation of projects and programmes was generally rated as good whiles its involvement in M\&E was rated as poor. This is in consonance with Hilhorst and Guijt (2006:3) who noted that while primary stakeholders are increasingly involved in some aspects of planning, their presence within the M\&E of actions is very often lacking or inadequate. Ahenkan et al. (2013: 206) also observed that there are no clear structures and procedures for community involvement in the monitoring of development interventions in the districts though some structures for promoting community engagement during planning processes exist. Evidence from the study gave an indication that M\&E of projects and programmes could be concentrated at the municipal level, hence the poor rating could be a result of the over concentration on participatory planning at the peril of PM\&E at the Zonal council level and that because participatory planning has been on the drawing board for long, there exist some appreciable level of involvement in planning.

\section{Frequency of involvement in M\&E of Projects and Programmes}

Regarding the level of participation of various categories of stakeholders in M\&E of projects and programmes, respondents participated in some form of M\&E of projects and programmes in the municipality over the last six-year period. Even 
though majority of the respondents have ever been involved in M\&E of projects and programmes in the last six years, majority of them (57\%) were rarely involved on quarterly basis while only $11 \%$ were involved quarterly as in Table 2.

Table 2: Frequency of involvement in M\&E of projects and programmes

\begin{tabular}{|c|c|c|c|c|c|c|c|c|}
\hline \multirow{2}{*}{$\begin{array}{l}\text { REGULARITY } \\
\text { OF } \\
\text { INVOLVEMENT }\end{array}$} & \multicolumn{2}{|c|}{ COMMUNITY } & \multicolumn{2}{|c|}{ MPCU } & \multicolumn{2}{|c|}{$\begin{array}{l}\text { SUB- } \\
\text { STRUCTURE }\end{array}$} & \multirow[t]{2}{*}{$\begin{array}{l}\text { Total } \\
\text { freq. }\end{array}$} & \multirow[t]{2}{*}{$\begin{array}{l}\text { Total } \\
\text { (\%) }\end{array}$} \\
\hline & Freq. & $\%$ & Freq. & $\%$ & Freq. & $\%$ & & \\
\hline Quarterly & 1 & 2 & 3 & 38 & 8 & 20 & 12 & 11 \\
\hline Yearly & 6 & 10 & 1 & 12 & 4 & 10 & 11 & 10 \\
\hline $\begin{array}{l}\text { As and when it is } \\
\text { organized. }\end{array}$ & 18 & 29 & 2 & 25 & 4 & 10 & 24 & 22 \\
\hline Rarely involved & 36 & 59 & 2 & 25 & 25 & 60 & 63 & 57 \\
\hline Total & 61 & 100 & 8 & 100 & 41 & 100 & 110 & 100 \\
\hline
\end{tabular}

It was also realised that the Municipal Planning and Co-ordinating Unit (MPCU) (57\%) and the Assembly members (68\%) are more involved in M\&E of projects and programmes in the beneficiary communities whereas the Zonal Council and the Unit Committees' involvement is low. This is in contrast with the findings of Azizu (2014) that grassroot participation in M\&E is fairly high in the Yilo Krobo Municipal Assembly. However, this is in line with Ahenkan et al. (2013:200) who found that assembly members are stakeholders with very high interest in the development of their district. However, the assembly members found it difficult to access information about the district's projects and programmes (Ahenkan, Bawole \& Domfer, 2013: 202). According to one Assembly member in the Moglaa Zonal Area of the Savelugu-Nanton Municipality:

Our electorates expect us to monitor projects on their behalf at all times with the thinking that we were voted to champion all development activities. Even some of the Unit Committees don't support us to visit projects and to report to the assembly or the council when something wrong is going on.

\section{Modes of stakeholders Involvement in PM \& E}

With regards to ways in which stakeholders participate in M\&E, it was established that stakeholders at the community and sub-structure level participated in M\&E of projects and programmes through stakeholder review meetings and majority also participated only through public hearing during the preparation of the M\&E plan (see Table 3). 
Table 3: Modes of involvement in M\&E plan preparation

\begin{tabular}{|l|l|l|l|l|l|l|l|l|}
\hline \multirow{2}{*}{$\begin{array}{l}\text { INVOLVEMENT } \\
\text { MODES }\end{array}$} & \multicolumn{2}{|l|}{ COMMUNITY } & \multicolumn{2}{|l|}{ MPCU } & \multicolumn{2}{l|}{$\begin{array}{l}\text { SUB- } \\
\text { STRUCTURE }\end{array}$} & \multicolumn{2}{l|}{ TOTAL } \\
\cline { 2 - 10 } & Freq. & $\%$ & Freq. & $\%$ & Freq. & $\%$ & Freq. & $\%$ \\
\hline General assembly & 7 & 23 & 1 & 10 & 5 & 29 & 13 & 25 \\
\hline $\begin{array}{l}\text { Consultation for } \\
\text { data }\end{array}$ & 3 & 10 & 1 & 10 & 2 & 12 & 6 & 11 \\
\hline $\begin{array}{l}\text { Public hearing } \\
\text { Throughout the }\end{array}$ & 0 & 67 & 1 & 10 & 10 & 59 & 31 & 60 \\
\hline process & 0 & 0 & 2 & 20 & 0 & 0 & 2 & 4 \\
\hline TOTAL & $\mathbf{3 0}$ & $\mathbf{1 0 0}$ & $\mathbf{1 0}$ & $\mathbf{1 0 0}$ & $\mathbf{1 7}$ & $\mathbf{1 0 0}$ & $\mathbf{5 2}$ & $\mathbf{1 0 0}$ \\
\hline
\end{tabular}

This indicates that the participation of stakeholders can best be described as tokenistic as noted by Anstein (1969) and consultation as noted by the Africa Development Bank (2001) and Wilcox, (2003). The Africa Development Bank (2001) described consultation as a prerequisite for participation encapsulating information sharing, listening and learning and joint assessment which can be likened to stakeholder review meetings and public hearing. This points out that more needs to be done to strengthen the level of participation in the M\&E of projects and programmes to achieve the best outcomes and impacts of projects and programmes.

\section{Impact of stakeholder participation on the performance of projects and programmes}

It was revealed that $29 \%$ and $32 \%$ of the community and sub-structure respondents that the people have high interest towards the maintenance of projects even though they are not largely involved in the M\&E of projects (see Table 4). This is partly due to the fact that they don't even know what is contained in the agreement between the service providers or the contractors and the Municipal Assembly. 
Table 4: Views on sustainability of projects and programmes

\begin{tabular}{|c|c|c|c|c|c|c|}
\hline \multirow[t]{2}{*}{ VIEWS } & \multicolumn{2}{|c|}{ COMMUNITY } & \multicolumn{2}{|c|}{ SUB-STRUCTURE } & \multicolumn{2}{|c|}{ TOTAL } \\
\hline & Freq. & $\%$ & Freq. & $\%$ & Freq. & $\%$ \\
\hline $\begin{array}{l}\text { The people have high interest } \\
\text { for the maintenance of projects } \\
\text { in the community }\end{array}$ & 37 & 29 & 19 & 32 & 56 & 31 \\
\hline $\begin{array}{l}\text { The people have poor attitude } \\
\text { towards projects as they think } \\
\text { they are for government/ } \\
\text { assembly }\end{array}$ & 80 & 64 & 29 & 48 & 109 & 57 \\
\hline $\begin{array}{l}\text { Some of the communities have } \\
\text { their own approach to project } \\
\text { maintenance }\end{array}$ & 5 & 4 & 4 & 7 & 9 & 5 \\
\hline $\begin{array}{l}\text { People think the sustainability } \\
\text { of projects is the responsibility } \\
\text { of assembly persons and } \\
\text { opinion leaders }\end{array}$ & 4 & 3 & 8 & 13 & 12 & 7 \\
\hline Total & 126 & 100 & 60 & 100 & 186 & 100 \\
\hline
\end{tabular}

The Assembly Member at Pigu, for instance, proverbially noted that: If you don't see when a monkey climbed a tree, how can you know when it will get down from the tree. What the Assembly Member meant was that if you don't know the conditions and agreements attached to a project or programme and what exactly the service provider or contractor is expected to do or not to do, how can you monitor the project very well. This statement runs deep as far as the relationship between monitoring and the sustainability of projects in the communities is concerned. It raises several questions on how communities have been positioned to own and sustain development projects and programmes long after service providers and contractors have exited. This is consistent with the report of Hilhorst and Guijt (2006:43), that access to complete project information provides people with a sound basis to voice their concerns and needs, which can be incorporated into project activities. Moreover, wide public dissemination helps to place control in the hands of communities and mitigates risks of manipulation by other actors and that once the project began it is important to ensure that the communities stay informed, receive feedback on progress at different stages. Therefore access to complete project information from inception to completion can whip up the interest of beneficiary communities and their representatives to contribute to maintain the project after the project has been handed over to the community. 


\section{Table 5: Summary of results}

\begin{tabular}{|l|l|}
\hline $\begin{array}{l}\text { Stakeholder involvement } \\
\text { in project/programme } \\
\text { planning, implementation, } \\
\text { M\&E. }\end{array}$ & $\begin{array}{l}\text { The results showed a strongest rejection of the statement that } \\
\text { project/programme monitoring and evaluation should be a sole } \\
\text { responsibility of MPCU (49.2\% Community members, followed by } \\
\text { the Local Government substructure study respondents (35\%) and } \\
30 \% \text { of members of the MPCU). }\end{array}$ \\
\hline $\begin{array}{l}\text { Level of participation of } \\
\text { the various categories of } \\
\text { stakeholders. }\end{array}$ & $\begin{array}{l}57 \% \text { of respondents indicated that they rarely participated in } \\
\text { quarterly monitoring and evaluation of projects/programmes. }\end{array}$ \\
\cline { 2 - 3 } & $\begin{array}{l}\text { There was low level of stakeholder involvement in M\&E of projects } \\
\text { and programmes. } \\
\text { Low community participation in stakeholder monitoring and } \\
\text { evaluation stems from the fact that they were not involved in the } \\
\text { initial planning stages in addition to political interferance in project } \\
\text { planning and implementation, which have all negatively affected } \\
\text { project/programme sustainability. }\end{array}$ \\
\hline $\begin{array}{l}\text { Ways in which stakeholders } \\
\text { participate in the M\&E of } \\
\text { projects and programmes }\end{array}$ & $\begin{array}{l}\text { The participation of stakeholders in monitoring and evaluation } \\
\text { through review meetings and public hearings can best be described } \\
\text { as tokenistic. }\end{array}$ \\
\hline $\begin{array}{l}\text { Impact of stakeholder } \\
\text { participation on the } \\
\text { performance of projects and } \\
\text { programmes }\end{array}$ & $\begin{array}{l}\text { 29\% and 32\% of the community and sub-structure respondents that } \\
\text { the people have high interest in the maintenance of projects even } \\
\text { though they are not largely involved in the M\&E of projects. This } \\
\text { impacted negatively on project/programme outputs and outcomes; } \\
\text { especially in the case of ensuring value for money. }\end{array}$ \\
\hline
\end{tabular}

The main objective of the study was to establish the level of stakeholder participation in M\&E of projects and programmes in the SNMA. The study has established that stakeholders were rarely involved in M\&E of projects and programmes. The study also revealed that the MPCU and the Assembly members' involvement were appreciably high whereas the Unit committee, the community and the Zonal councils' involvement were low. The study has established also that stakeholders mostly participated in M\&E through stakeholder review meetings to be provided with information on the progress of work regarding projects and programmes. This level of participation can best be described as consultation and tokenistic which does not represent deeper levels of participation. This is as a result of lack of concerted effort by the MPCU for grass root stakeholder participation and poor attitude on the part of community level stakeholders in M\&E of projects and programmes. 
In the light of this situation, the District Assembly through the MPCU should establish strategies such as increased engagement of the substructures in the planning, implementation, monitoring and evaluation process, creating an enabling environment for the substructures to set their own targets, support them to meet the targets and build their capacities to report regularly to communities under them and to the Municipal. The Municipal Assembly should also team up with the Sub-structures to increase the sensitization of community members.

\section{Conclusion}

The study has established that stakeholders mostly participated in M\&E through stakeholder review meetings to be provided with information on the progress of work regarding projects and programmes. This level of participation can best be described as consultation and tokenistic which does not represent deeper levels of participation. Keeping some members of the grassroots out of M\&E raised questions of transparency and accountability in the execution of projects and programmes. Meanwhile effective participation of stakeholders in M\&E of projects and programmes can improve transparency, accountability, project and programme sustainability and ensure positive community level stakeholder attitude to projects. This can be achieved by increasing the level of participation of key stakeholders beyond information giving and consultation. There is the need to strengthen the district sub-structures, form community level project monotoring and evaluation management committees and the sensitisation of beneficiary communities of projects and programmes on the need to participate in the monitoring and evaluation of projects and programmes. Metropolitan, Municipal and District Assemblies in Ghana need to re-think stakeholder participation in the development process in general and in the process of monitoring and evaluation in order to ensure effectiveness and efficiency in projects' and programmes' delivery. 


\section{References}

African Development Bank. (2001). Handbook on Stakeholder Consultation and Participation in ADB Operations. Abidjan, Cote Divoire: OESU.

Ahenkan , A., Bawole, N. and Domfer, K. (2013). Improving Citizens' Participation in Local Government Planning and Financial Management in Ghana: A Stakeholder Analysis of the Sefwi Wiawso Municipal Assembly, Vol. 3, No. 2. Journal of Public Administration and Governance, pp.191-208.

Alfred, A. (2015). Enahancing Stakeholder's Involvement In Project Monitoring Among Metropolitan, Municipal and district Assemblies:A Case Study of Atwima Mponua District Assembly. http://www.google.com.gh

Arnstein, S. R. (1969). Ladder of Citizen Participation. "The City Reader" (second edition) edited by Richard T. Gates and Frederic Stout, 1996, Routledge Press. Originally published as Arnstein, Sherry R. A Ladder of Citizen Participation, JAIP, Vol. 35, No. 4, July 1969, pp. 216-224, 1-14.

Burns, D., Hambleton, R. and Hoggett, P. (1994). Citizen Participation: Theory and Practice. The Politics of Decentralisation: Revitalising Local Democracy (153-179). London: The Macmillan Press Ltd, retrieved from http//www. ourkidsnetwork.ca, 16/07/2017.

Collins, K. (1996). Participatory Evaluation in Programmes Involving Governance Decentralisation: A Methodological Note. Draft Private. New York: UNDP.

Coupal, F. (2001). Results-based Participatory Monitoring and Evaluation, CIDA's Performance Review. Ottawa, K2A 2A8, Canada: Mosaic Net International.

Creswell, J. W. (2009). Research Design, Qualitative, Quantitative and Mixed Methods Approaches (Third Edition). California, London, New Delhi: Sage Publications, Inc.

Devas, N. and Grant, U. (2003). Local Government Decision-Making-Citizen Participation and Local Accountability: Some Evidence from Kenya and Uganda. Public Administrative Development, 23 (307-316), pp.203-308.

DPCU, SNDA. (2010). Monitoring and Evaluation plan 2010 - 2013. Savelugu: SaveluguNanton Municipal Assembly.

Flick, U. (Eds.) (2009). An Introduction to Qualitative Research (4th ed.). London: Sage Publication Ltd., pp. 123.

GSS. (2014). 2010 Population and Housing Census, District Analytical Report, Savelugu-Nantong District. Accra: Ghana Statistical Service. 
Hilhorst, T. and Guijt, I. (2006). Participatory Monitoring and Evaluation:A process to Support Governance and Empowerment at the Local Level. Amsterdam, Netherlands: World Bank, Royal Tropical Institute, pp. 1-6o.

IDS. (1998). Participatory Monitoring and Evaluation: Learning from Change. Policy Brief 12, Brighton BN1 9RE, UK: Institute of Development Studies, University of Sussex, pp.1.

ILGS. (2010). A Guide to District Assemblies in Ghana. Accra: Friedrich-EbertStiftung Ghana.

MPCU,SNMA. (2015). Implementation of District Medium Term Development Plan (2014-2017), Annual progress Report for 2014. Savelugu: Savelugu-Nanton Municipal Assembly, pp. 9.

Kothari, C. R. (Eds.) (2004). Research Methodology, Methods and Techniques (2nd ed.). India: New Age Publication, pp. 175.

Nyaguthii , E. and Oyugi , L. A. (2013). Influence of Community Participation on Successful Implementation of Constituency Development Fund Projects in Kenya: Case Study of Mwea Constituency. International Journal of Education and Research, 1 (8), pp. 9-22.

Oreyo Otieno, J., Munyua, C. N. and Olubandwa, A. (2016). Effects of Participatory Monitoring and Evaluation on Stakeholder Relationships and Project Quality in the Local Authority Service Delivery Action Planning (LASDAP) Process in Bondo Sub County in Siaya County, Kenya. Developing Country Studies,6 (4), pp. 82-86.

Rajalahti, R., Woelcke, J. and Pehu, E. (2005). Monitoring and Evaluation for World Bank Agricultural Research and Extension Projects: A Good Practice Note, Agriculture and Rural Development Discussion Paper 20. Washington, DC: The International Bank for Reconstruction and Development / The World Bank.

Shah, M. K., Mahlalela, X. M., Kambou, S. D. and Adams, M. K. (2006). Participatory Monitoring and Evaluation of Community - and Faith-Based Programs Manual: A step-by-step guide for people who want to make HIV and AIDS services and activities more effective in their community, Second Edition. Washington DC, USA: Core Initiative/USAID.

Sulemana, M. and Ngah, I. (2012). Participatory Planning: Ending the Controversies. European Journal of Social Sciences, 28 (1), pp. 24-34.

Wilcox, D. (2003). The Guide to Effective Participation. Brighton, UK: Joseph Rowntree:http://www.partnerships.org.uk Accessed: 15/07/201. 
World Bank. (1998). Participation and the World Bank Success, Constraints, and Responses. Washington, D.C. 20433 USA: Social Development Family of the World Bank.

World Bank. (2010). World Development Report. New York: Oxford University Press.

Yin, R. K. (2003). Case Study Research: Design and Methods. (3rd Edition). Applied Social Research Methods Series Vol.5. Beverly Hills: Sage Publications.

Yin, R. K. (2004). Case Study Methods, Revised Draft. Washington, DC: Cosmos Corporation.

Yin, R. K. (Eds.) (2009). Case Study Research. Design and Methods. (4th ed.). Thousand Oaks: Sage Publications. 